\title{
PENINGKATAN EFISIENSI DAN KAPASITAS PRODUKSI PADA PROSES PENGOLAHAN SAMBEL PECEL, KERIPIK TEMPE DAN KERIPIK SINGKONG
}

\author{
Improvement of Eficiency and Production Capacity of Pecel Sauce, \\ Tempeh Chips and Cassava Chips Processing \\ Novita Wijayanti dan Indria Purwantiningrum \\ Fakultas Teknologi Pertanian - Universitas Brawijaya, Jl. Veteran, Malang \\ Email: n_wijayanti@ub.ac.id; wijayantinovita@gmail.com
}

\begin{abstract}
"KUB Mekar Sari", in Minggir Sari Village, Kanigoro District, Blitar City is a group of women farmers who have a processed food business. They used manually equipment that less efficient in their food processing. The condition causes production capacity was still limited. The activity of "IbM KUB Mekar Sari" program aims to help UKM increase efficiency and production capacity through technology transfer of production equipment. So, the various problems of three UKMs were getting a solution. Technology transfer implemented in this program were nut roasters machine and grinders for pecel sauce UKM, industrial stove and vertical packaging machine for tempeh chips UKM, and also cassava slicer and spinner for cassava chips UKM. This program was implemented by training, mentoring, testing equipments to ensure the effectiveness of the technology transfer and also mentoring implementation of Good Manufacturing Process (GMP) for KUB Mekar Sari until they can maintain the products quality, ensure the food safety and able to fulfill consumer demand. The results of technology transfer showed an increase in the production efficiency. The use of shorter time can obtain results with greater capacity and better quality. So they can produce food products that are ready to compete in the Market.
\end{abstract}

Keywords: Blitar tempeh chips, draining the oil, pecel sauce, slicing, roasting

\begin{abstract}
ABSTRAK
Kelompok Usaha Bersama (KUB) Mekar Sari di Desa Minggir Sari, Kecamatan Kanigoro, Kabupaten Blitar merupakan kelompok wanita tani yang memiliki usaha pangan olahan. UKM tersebut masih menggunakan peralatan manual sehingga kurang efisien dalam proses produksinya. Kondisi tersebut menyebabkan kapasitas produksi masih terbatas. Kegiatan IbM Kelompok Usaha Bersama Mekar Sari ini bertujuan untuk membantu mitra meningkatkan efisiensi dan kapasitas produksi melalui alih teknologi peralatan produksi sehingga berbagai permasalahan yang dihadapi ketiga UKM mitra ini memperoleh solusi. Alih teknologi yang dilaksanakan dalam program ini adalah alat penyangrai dan penggiling kacang untuk UKM sambel pecel, kompor industry dan pengemas kontinyu untuk UKM keripik tempe, serta mesin perajang dan spinner untuk UKM keripik singkong. Program ini dilaksanakan dengan pelatihan, pendampingan dan uji coba alat untuk memastikan efektivitas alih teknologi serta pendampingan penerapan Cara Produksi Pangan yang Baik (CPPB) bagi KUB Mekar Sari, sehingga mereka dapat menjaga kualitas produk, menjamin keamanan pangan dan dapat memenuhi permintaan konsumen. Hasil alih teknologi menunjukkan peningkatan efisiensi produksi. Penggunaan waktu yang lebih singkat dapat memperoleh hasil dengan kapasitas yang lebih besar dan kualitas yang lebih baik, sehingga mereka dapat menghasilkan produk yang siap bersaing di Pasaran.
\end{abstract}

Kata kunci: keripik tempe, penirisan minyak, penyangraian, perajangan, sambel pecel 


\section{PENDAHULUAN}

Desa Minggirsari merupakan salah satu desa yang terletak di Kecamatan Kanigoro. Desa ini adalah desa agraris yang merupakan pengembangan Kecamatan Kanigoro sebagai ibukota Kabupaten Blitar. Blitar merupakan salah satu dari kota agropolitan di Jawa Timur. Hal ini berimbas pada pemberdayaan desa sebagai desa yang bergerak dalam bidang agribisnis. Oleh karena itu, warga wanita dari desa Minggirsari yang telah mempunyai usaha pangan olahan mendirikan suatu Kelompok Usaha Bersama (KUB) "Mekar Sari” yang berawal dari kelompok wanita tani.

$\begin{array}{ccc}\text { KUB } & \text { "Mekar } & \text { Sari" merupakan } \\ \text { kelompok } & \text { usaha } & \text { bersama yang }\end{array}$ memproduksi hasil pertanian dalam bentuk pangan olahan di Desa Minggirsari, Kecamatan Kanigoro, Kabupaten Blitar. Beberapa industri UKM yang tergabung dalam KUB "Mekar Sari", meliputi: UKM sambel pecel merek "Pas Mantab" milik ibu Sri Mulyati, UKM keripik tempe merek "Yupi" milik ibu Sri Hartati dan UKM keripik singkong "Alam Sari” milik ibu Dwi Langgeng Rahayu.

Ibu Sri Mulyati memproduksi sambel pecel khas Blitar dengan merek "Pas Mantab" dan PIRT No. 215350501449. Setiap hari membutuhkan $12,5 \mathrm{~kg}$ kacang tanah mentah untuk membuat sambel pecel. Produknya dikemas bervariasi dalam plastik ukuran 100; 200 dan 500 gram. Selain itu, ada kemasan dalam dus yang berisi 5 plastik kecil ukuran 100 gram (Gambar 1). Produk sambel pecel Ibu Sri Mulyati dijual dengan harga dijual Rp. 30.000 per kg. Sambel pecel kemasan $0,5 \mathrm{~kg}$ dijual Rp. 15.000 yang kemudian oleh toko dijual bervariasi Rp. 18.000-21.000. Selain di Blitar, wilayah pemasaran sambel pecel ini telah mencapai Malang, dan Surabaya dengan sistem konsinyasi putus.

Selain sambel pecel, produk olahan dari KUB "Mekar Sari" adalah keripik tempe yang diolah oleh Ibu Sri Hartati dengan PIRT No. 21535050301. Keripik tempe khas Blitar merek "Yupi" ini berbeda dengan keripik tempe Malang atau Bandung. Biasanya keripik tempe dibuat dengan cara melakukan pengirisan balok tempe yang sudah jadi. Namun, keripik tempe buatan bu Sri Hartati ini terbuat dari tempe tipis yang dibuat secara individual, sehingga tidak perlu dilakukan pengirisan balok tempe. Keuntungan dari keripik tempe khas Blitar yaitu diperoleh jumlah kapang tempe yang lebih banyak dibandingkan proses pengolahan keripik tempe yang dilakukan pengirisan.

Keripik tempe adalah makanan ringan yang terbuat dari tempe. Tempe merupakan makanan tradisional Indonesia yang terbuat dari kedelai yang difermentasi dengan Rhizopus sp. Tempe memiliki zat gizi tinggi yang mudah diserap oleh tubih dan kaya akan isoflavon yang sangat baik untuk kesehatan sehingga tempe juga termasuk pangan fungsional (Nakajima et al., 2005).

Kacang kedelai dikuliti dan dibersihkan dari kotoran, kemudian direndam 30 menit pada suhu $25^{\circ} \mathrm{C}$, dan direbus selama 30 menit. Setelah dingin selanjutnya kacang kedelai kupas ditaburi dengan ragi, dibungkus menggunakan kertas dan dibentuk tipis. Fermentasi dilakukan selama 20-28 jam atau semalam sampai tempe jadi (Babu et al., 2009). Setelah itu lembaran tempe dicelupkan pada adonan tepung dan digoreng sampai kering.

Ibu Sri Hartati memproduksi $5 \mathrm{~kg}$ tempe per hari dibantu dengan dua orang pekerja. Keripik tempe tersebut dijual dalam kemasan 200 gram (Gambar 1) dengan harga Rp. 10.000. Keripik tempe merek "Yupi ini dipasarkan di wilayah Blitar dengan dititipkan di toko-toko dan swalayan.

Produk pangan olahan KUB "Mekar Sari" yang lain adalah keripik singkong yang diproduksi oleh Ibu Dwi Langgeng Rahayu. Keripik singkong dengan merek "Alam Sari” dan PIRT No. 21535050773 mempunyai beberapa macam varian rasa yaitu singkong rasa original, pedas, dan rasa gadung. Keripik singkong dikemas dalam plastik dengan ukuran 200 gram dengan harga Rp 10.000 per bungkus. Keripik 
singkong rasa gadung diolah dengan cara merendam rajangan singkong di dalam air selama 2 hari yang airnya diganti setiap hari. Menurut Tsav-Wua et al. (2004) selama perendaman singkong terjadi fermentasi bakteri asam laktat yang mengubah karakteristik singkong. Selanjutnya irisan singkong dikukus sampai pati tergelatinisasi dan kemudian dijemur hingga kering. Keripik singkong kering selanjutnya digoreng dan dikemas.

Secara umum ketiga UKM tersebut menjalankan usahanya secara manual dan tradisional, padahal mereka memiliki daya terima pasar yang cukup baik. Terlebih lagi jika mendapatkan pesanan yang cukup banyak maka mereka menghadapi masalah kapasitas produksi yang masih rendah karena proses produksi yang manual dan berjalan lambat. Selain permasalahan tersebut, UKM juga membutuhkan pembimbingan dan pendampingan dalam menerapkan CPPB (Cara-cara Pengolahan Pangan yang Baik). Hal ini dilakukan agar UKM dapat menjamin kesehatan dan keamanan pangan.

Penerapan alih teknologi sesuai dengan permasalahan mitra diharapkan mampu menjadi solusi terutama dalam peningkatan efisiensi dan kapasitas produksi.

Tujuan kegiatan ini adalah membantu UKM Mitra dalam meningkatkan efisiensi dan kapasitas produksi serta memperbaiki kualitas produk dan pengemasan yang dihasilkan, selanjutnya diharapkan dapat meningkatkan daya saing mitra di pasaran.

\section{METODE PELAKSANAAN}

Tahapan kegiatan yang dilakukan pada IbM Kelompok Usaha Bersama "Mekar Sari" ini meliputi:

1. Melakukan identifikasi mengenai segala permasalahan yang dihadapi oleh Mitra UKM yang tergabung dalam KUB "Mekar Sari"

2. Pengadaan fasilitas mesin dan peralatan untuk mendukung peningkatan efisiensi dan kapasitas produksi di KUB "Mekar
Sari”.

3. Kegiatan bimbingan teknis, pelatihan dan pendampingan mengenai pemakaian mesin dan peralatan

4. Pendampingan dalam penerapan CPPB dalam proses pengolahan produk pangan oleh ketiga mitra. Pembinaan sikap pencegahan terhadap kesalahan yang berakibat kontaminasi makanan dengan tindakan tepat dan didukung dengan penggunaan fasilitas yang bersih

5. Pembinaan dalam peningkatan kualitas produk dengan menggunakan bahan tambahan pangan yang aman dan kadar yang tepat serta pencegahan pemakaian minyak secara berulang

6. Perbaikan dalam bentuk kemasan agar lebih menarik, lebih mudah dalam mengkonsumsi, lebih tahan lama dan lebih memperhatikan keseragaman mutu kemasan sehingga dapat menurunkan resiko kemasan cacat.

7. Mencari peluang-peluang baru dalam memperluas pemasaran produk misalnya pemasaran secara online

\section{HASIL DAN PEMBAHASAN}

Khalayak sasaran strategis yang dilibatkan dalam pelaksanaan kegiatan pengabdian kepada masyarakat ini adalah Kelompok Usaha Bersama "Mekar Sari" di Desa Minggir Sari, Kecamatan Kanigoro, Kabupaten Blitar yang mengolah produk pangan, meliputi: sambal pecel, keripik tempe dan keripik singkong yang disajikan dalam Gambar 1.

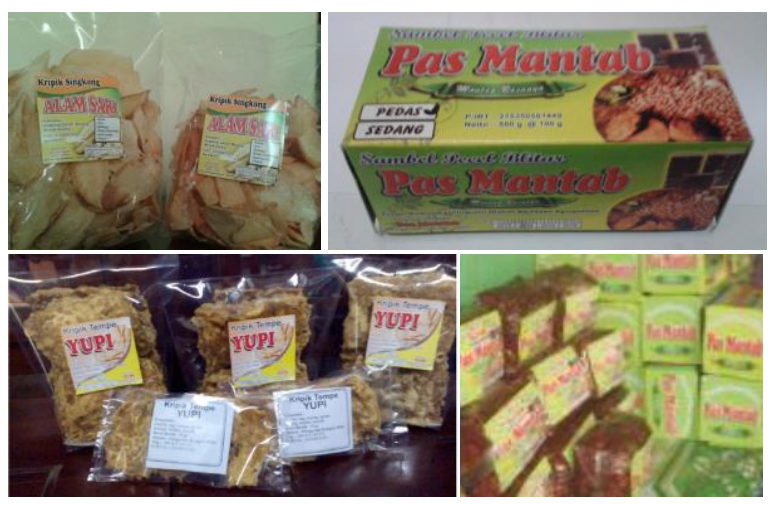

Gambar 1. Produk Pangan KUB Mekar Sari 
Program IbM ini ditujukan untuk menyelesaikan permasalahan yang dihadapi oleh mitra KUB "Mekar Sari" berdasarkan pada masing-masing permasalahan yang dihadapi mitra yaitu meliputi:

\section{Mekanisasi Proses Pembuatan Bumbu Pecel "Pas Mantab"}

Mekanisasi produksi bumbu pecel diperlukan untuk meningkatkan efisiensi proses sehingga berdampak pada peningkatan kapasitas produksi mitra. Peningkatan kapasitas produksi dilakukan dengan alih teknologi alat penyangrai kacang.

Selama ini, Mitra menggunakan oven untuk memanggang kacang. Kelemahan alat ini adalah pemanasan dari oven kurang merata di setiap tingkat, sehingga perlu dilakukan pemindahan tempat dalam selang waktu tertentu. Jika tidak dilakukan pemindahan maka akan terjadi kematangan yang tidak merata bahkan gosong. Proses pemanggangan menggunakan oven ini membutuhkan waktu sekitar 4 jam untuk memanggang 12,5 kg kacang. Oleh karena itu, proses ini memakan waktu yang lama dan kurang efisien terhadap pengunaan tenaga kerja.

Alih teknologi pada Mitra UKM "Pas Mantab" dengan menggunakan mesin penyangrai kacang seperti terlihat pada Gambar 2. Mesin penyangrai kacang ini memiliki dua arah putaran yang berbeda. Arah yang berlawanan dengan ujung outlet digunakan jika sedang melakukan proses penyangraian. Putaran ini berfungsi agar posisi kacang tidak hanya di bawah (sumber panas) tetapi berputar ke atas dan ke bawah lagi sehingga kacang tidak gosong dan matang secara merata. Arah yang sama dengan ujung outlet berfungsi untuk mengeluarkan kacang ketika proses penyangraian telah selesai. Dengan menggunakan alat ini dapat menyangrai kacang sebanyak $12,5 \mathrm{~kg}$ selama 15 menit. Hal ini sangat membantu Mitra dalam mempercepat waktu proses pemanggangan kacang.
Proses pemanasan kacang yang merata sangat diperlukan untuk mendapatkan kualitas sambel pecel yang tidak mudah tengik. Karena kacang-kacangan memiliki kandungan lipase dengan aktivitas tinggi Pemanasan pada kacangan-kacangan dapat berfungsi untuk menginaktivasi lipase yang berperan menghidrolisis trigliserida menjadi asam lemak bebas yang mudah teroksidasi (Pahoja dan Sethar, 2004).

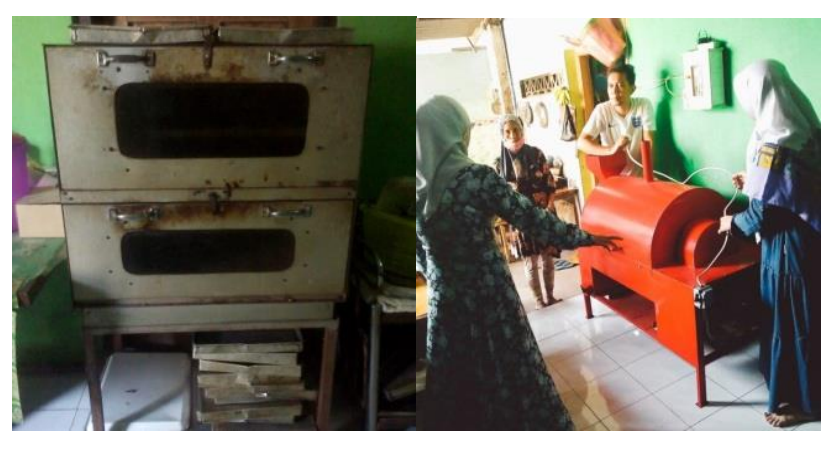

(a)

(b)

Gambar 2. Peralatan yang digunakan untuk mengeringkan kacang oleh UKM "Pas Mantab"

(a) Oven lama, (b) Mesin penyangrai kacang

Biji kacang tanah tergolong mudah terkontaminasi aflatoksin, yang merupakan hasil metabolisme sekunder jamur Aspergillus flavus, Aspergillus parasiticus, dan Aspergillus nomius. Kadar air biji, suhu, dan kelembaban relatif selama dalam perjalanan dan penyimpanan pada rantai perdagangan kondusif bagi peningkatan infeksi jamur Aspergillus flavus dan produksi aflatoksin (Rahmianna dkk., 2007).

Kadar aflatoksin dapat diturunkan dengan menggunakan proses penyangraian. Penurunan kadar aflatoksin dipengaruhi oleh suhu dan waktu penyangraian. Kacang yang memperoleh perlakuan sangrai $150^{\circ} \mathrm{C}$ selama 30 menit dapat menurunkan kadar aflatoksin (Yazdanpanah et al., 2005). Oleh karena itu, dengan penggunaan alat penyangrai ini dapat menurunkan resiko adanya aflatoksin pada sambel pecel.

Peralatan lain yang dibutuhkan oleh Mitra UKM "Pas Mantab" adalah mesin penggiling (Gambar 3). Mesin ini dapat 
digunakan untuk menghaluskan sekaligus mencampur antara bumbu dan kacang tanah yang sudah disangrai. Dengan menggunakan alat ini akan dapat mempercepat proses pembuatan sambel pecel. Selain itu juga akan menghasilkan adonan yang tercampur rata dan memiliki partikel yang lebih seragam.

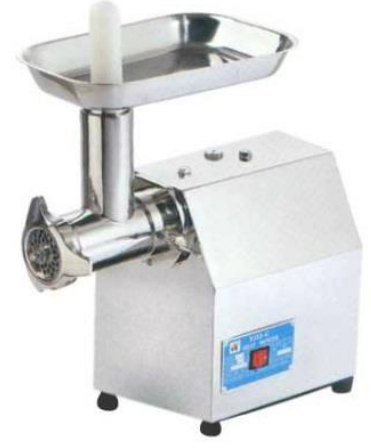

Gambar 3. Mesin Penggiling Bumbu

\section{Peningkatan Kapasitas Produksi dan Efisiensi Pengemasan Keripik Tempe Merk "Yupi"}

Peningkatan efisiensi dan kapasitas produksi keripik Tempe "Yupi" dilakukan dengan menyediakan kompor cor industri (Gambar 4). Selama ini Mitra menggunakan kayu bakar untuk menggoreng karena jika menggunakan kompor rumah tangga, kurang mampu memberikan panas yang cukup pada wajan yang besar. Jumlah kompor yang hanya satu akan memperlama waktu produksi mengakibatkan mitra menggunakan kompor secara bergantian dengan perebusan kedelai.

Proses penggorengan keripik tempe juga memakan waktu lama yaitu memerlukan waktu 4 jam untuk $5 \mathrm{~kg}$ tempe. Dengan adanya tambahan kompor ini diharapkan akan mempercepat proses produksi keripik tempe. Ketika melakukan perebusan kedelai juga bisa dilakukan bersamaan dengan proses penggorengan kripik tempe. Sehingga proses produksinya dua kali lebih cepat.

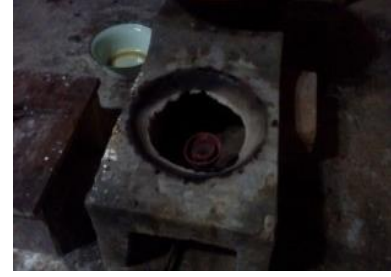

(a)

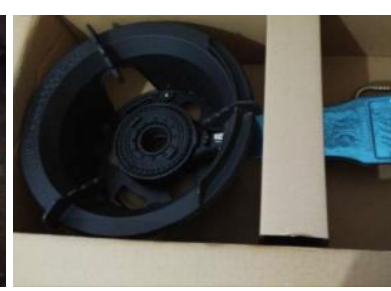

(b)
Gambar 4. Kompor yang Digunakan oleh Mitra Produsen Keripik Tempe.

(a) Kompor Lama, (b) Kompor Baru

Selain kompor industri, Mitra juga membutuhkan pengemas kontinyu vertikal untuk mengefisienkan proses pengemasan. Selama ini, proses pengemasan yang digunakan mitra dengan menggunakan pengemas manual yang memakan waktu lama. Mesin pengemas manual ini juga memiliki kelemahan yaitu jika tidak teliti terkadang ada bagian yang plastik yang belum terekat sehingga memungkinkan udara dapat masuk ke dalam kemasan. Jika hal ini dibiarkan maka keripik akan menurun kerenyahannya. Kadang untuk mengatasi hal tersebut, Mitra melakukan sealing sejajar sebanyak dua kali. Hal ini membuat tampilan kemasan kurang bagus.

Pada kegiatan ini dilakukan pengadaan mesin pengemas vertikal bagi mitra seperti yang dapat dilihat pada Gambar 5 . Pengadaan mesin pengemas vertikal ini membantu mitra terutama pada saat jumlah produksi cukup besar sehingga waktu pengemasan menjadi lebih singkat.

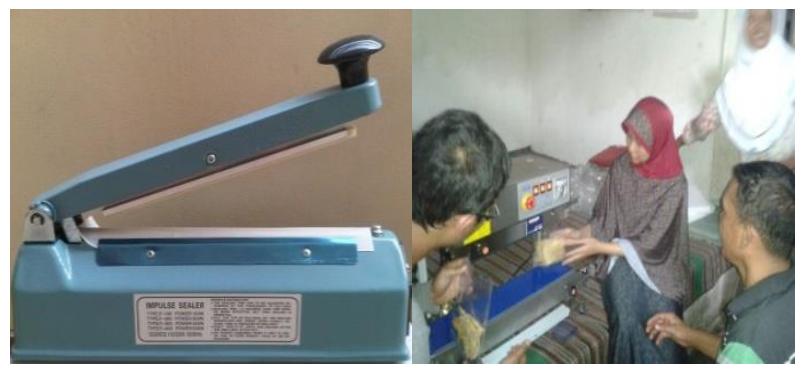

Gambar 5. Mesin Pengemas yang digunakan oleh UKM Keripik Tempe "Yupi"

(a) Alat Pengemas Manual, (b) Sealer Continous 
Mesin pengemas vertikal semi otomatis memiliki beberapa keunggulan yaitu bagian plastik yang merekat lebih lebar sehingga menjamin kemasan tidak bocor sehingga keripik tempe lebih renyah dalam waktu yang lebih lama, pengaturan suhu yang berkaitan dengan ketebalan plastik yang digunakan, pengaturan kecepatan seal dan kestabilan suhu. Pengaturan tanggal kadaluarsa juga bisa dilakukan dan tercetak di bagian plastik yang terekat.

\section{Peningkatan Kapasitas Produksi dan Mutu Keripik Singkong "Alam Sari"}

Peningkatan kapasitas produksi dan mutu keripik singkong "Alam Sari" dilakukan dengan alih teknologi mesin perajang dan spinner. Selama ini Mitra melakukan perajangan singkong dengan menggunakan alat perajang manual yang terbuat dari kayu. Kelemahan alat ini adalah proses manual yang seringkali menyebabkan tangan mitra menjadi terluka akibat kena mata pisau, sehingga resiko kecelakaan kerja yang dihadapi oleh karyawan lebih tinggi. Selain itu ketebalan singkong hasil perajangan tidak seragam danprosesnya membutuhkan waktu yang lama.

Selain itu alat perajang manual mempunyai kapasitas yang rendah akibat pisau yang digunakan sering tumpul dan dilakukan dengan cara manual. Jika menggunakan alat perajang manual ini akan menghabiskan waktu selama 2 jam untuk 5 kg umbi singkong.

Fasilitas mesin yang dibutuhkan oleh Mitra adalah mesin perajang (Gambar 6). Mesin perajang ini dilengkapi dengan pisau perajang yang bisa diatur ketebalannya serta diberi selubung pelindung berbentuk setengah lingkaran. Selain itu juga memiliki saklar pengaman dan gagang pendorong bahan yang terbuat dari stainless steel sehingga aman bagi pengguna.
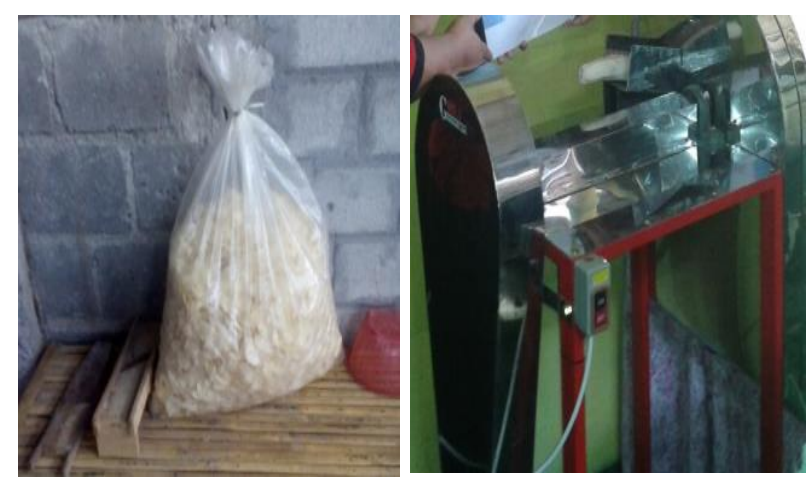

Gambar 6. Alat Perajang yang Digunakan oleh UKM Kripik Singkong "Alam Sari”

(a) Alat Perajang Lama, (b) Mesin Perajang

Kapasitas mesin perajang ini mencapai $100 \mathrm{~kg}$ per jam, sehingga untuk merajang $5 \mathrm{~kg}$ umbi singkong yang biasanya membutuhkan waktu 2 jam dapat dipersingkat menjadi 3 menit. Hal ini sangat membantu mitra dalam mempercepat proses produksi.

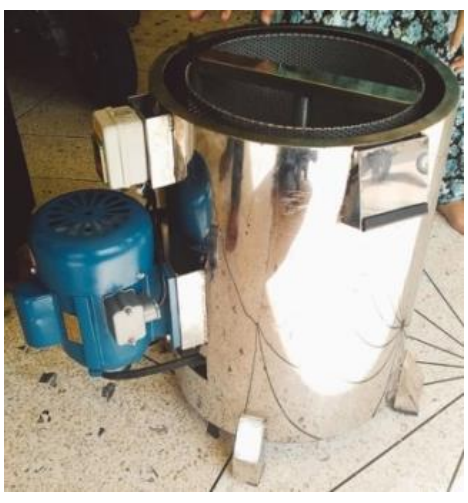

Gambar 7. Spinner

Peralatan lain yang dibutuhkan untuk meningkatkan kualitas produk adalah spinner (Gambar 7). Spinner memiliki fungsi untuk menghilangkan atau meniriskan minyak. Selama ini mitra melakukan penirisan dengan menggunakan keranjang dan didiamkan beberapa lama. Hal ini masih memungkinkan adanya minyak yang menempel pada produk karena tidak ada gaya mekanis yang dapat memisahkan minyak dengan produk. 
Seperti halnya perajang mekanis, spinner juga sangat membantu dalam mempersingkat waktu penirisan minyak. Dengan demikian waktu tunggu untuk pengemasan produk juga lebih singkat. Hal ini berarti penurunan resiko pencemaran produk selama waktu tunggu juga meningkat.

Adanya spinner ini tentu saja dapat meningkatkan kualitas keripik singkong karena dapat meminimalkan jumlah minyak yang melekat pada keripik. Hal ini akan mencegah proses oksidasi oleh lipid yang menyebabkan ketengikan pada produk. Menurut Pilli et al. (2008) salah satu reaksi yang terjadi selama pengolahan adalah oksidasi lipid yang menentukan keamanan dan kualitas produk. Perubahan aroma dapat terjadi akibat oksidasi yang disebabkan oleh pembentukan senyawa volatil berbau serta perubahan warna menjadi kecokelatan akibat produk oksidasi bereaksi dengan protein.

\section{Pendampingan penerapan CPPB di ketiga mitra}

CPPB merupakan salah satu faktor penting untuk memenuhi standar kualitas atau persyaratan keamanan pangan yang telah ditetapkan untuk pangan. CPPB sangat berguna bagi kelangsungan hidup industri pangan baik yang berskala kecil, sedang, maupun yang berskala besar (Wahono, 2007). Dengan menghasilkan pangan yang bermutu dan aman untuk dikonsumsi, kepercayaan masyarakat niscaya akan meningkat, dan industri pangan yang bersangkutan akan berkembang pesat. Oleh karena itu dalam kegiatan ini, tim juga memberikan pengenalan dan edukasi CPPB yang selanjutnya harus diterapkan oleh ketiga Mitra. Perlu perombakan yang cukup besar baik dalam memperbaiki sarana maupun prasarana untuk menerapkan CPPB secara komprehensif oleh ketiga mitra.

Langkah awal yang dapat dilakukan adalah memperbaiki sanitasi dan hygiene termasuk hygiene produk, menghindari kontak langsung dengan produk untuk menghindari kontaminasi, perbaikan metode penyimpanan untuk bahan baku dan produk jadi, serta pembatasan penggunaan minyak goreng bekas. Selanjutnya tetap diperlukan kegiatan pemantauan dalam penerapan CPPB dalam proses pengolahan produk pangan oleh mitra.

Ringkasan hasil kegiatan alih teknologi dapat dilihat pada Tabel 1.

Tabel 1.Peningkatan Efisiensi Kapasitas dan Produksi Pangan Olahan di KUB "Mekar Sari”

\begin{tabular}{|c|c|c|c|c|c|c|}
\hline \multirow{3}{*}{ Produk } & \multirow{3}{*}{ Tahapan Proses } & \multicolumn{4}{|c|}{ Jumlah dan waktu proses } & \multirow{3}{*}{$\begin{array}{c}\text { Peningkatan } \\
\text { Kapasitas }\end{array}$} \\
\hline & & \multicolumn{2}{|c|}{ Saat ini } & \multicolumn{2}{|c|}{ Setelah program } & \\
\hline & & Jumlah & Waktu & Jumlah & Waktu & \\
\hline \multirow[t]{2}{*}{ Keripik tempe } & $\begin{array}{l}\text { Penggorengan keripik } \\
\text { tempe }\end{array}$ & $5 \mathrm{~kg}$ & 4 jam & $5 \mathrm{~kg}$ & $2 \mathrm{jam}$ & 2 kali \\
\hline & $\begin{array}{l}\text { Pengemasan keripik } \\
\text { tempe }\end{array}$ & $5 \mathrm{~kg}$ & 2 jam & $5 \mathrm{~kg}$ & $1 / 2 \mathrm{jam}$ & 4 kali \\
\hline \multirow[t]{2}{*}{ Sambel pecel } & $\begin{array}{l}\text { Penyangraian kacang } \\
\text { tanah }\end{array}$ & $12,5 \mathrm{~kg}$ & 4 jam & $12,5 \mathrm{~kg}$ & $\begin{array}{r}15 \\
\text { menit }\end{array}$ & 16 kali \\
\hline & Pencampuran bahan & $12,5 \mathrm{~kg}$ & $2 \mathrm{jam}$ & $12,5 \mathrm{~kg}$ & $1 \mathrm{jam}$ & 2 kali \\
\hline \multirow{3}{*}{$\begin{array}{l}\text { Keripik } \\
\text { singkong }\end{array}$} & Perajangan & $5 \mathrm{~kg}$ & 2 jam & $100 \mathrm{~kg}$ & $1 \mathrm{jam}$ & 40 kali \\
\hline & Penggorengan & $1 / 2 \mathrm{~kg}$ & batch & $2 \mathrm{~kg}$ & batch & 4 kali \\
\hline & Penirisan minyak & Belum di & akukan & Sudah dilc & cukan & \\
\hline
\end{tabular}




\section{KESIMPULAN}

Kegiatan alih teknologi yang dilakukan sangat memberikan dampak positif bagi mitra. Peningkatan efisiensi dan kapasitas produksi pada proses penyangraian dan penggilingan kacang, perbaikan kualitas pengemasan dengan menggunakan mesin pengemas vertikal semi otomatis, peningkatan kapasitas penggorengan, peningkatan kapasitas perajangan serta penurunan retensi minyak, memberikan manfaat positif terhadap kemampuan mitra memenuhi permintaan pasar.

\section{UCAPAN TERIMA KASIH}

Ucapan terima kasih disampaikan kepada beberapa pihak, yaitu:

1. Direktorat Penelitian dan Pengabdian kepada Masyarakat, Direktorat Jenderal Pendidikan Tinggi, Kementerian Riset, Teknologi dan Pendidikan Tinggi atas pendanaan kegiatan melalui skim Iptek bagi Masyarakat (IbM) Tahun 2016 dengan Nomor Penugasan: 019/SP2H/ PPM/DRPM/II/2016 tanggal 18 Februari 2016.

2. Lembaga Penelitian dan Pengabdian kepada Masyarakat Universitas Brawijaya yang telah bekerjasama dalam pelaksanaan kegiatan IbM ini.

3. Mitra UKM yang tergabung dalam KUB "Mekar Sari" yang telah berpartisipasi aktif dalam pelaksanaan kegiatan IbM ini.

\section{DAFTAR PUSTAKA}

Babu P.D., Bhakyaraj R., and Vidhyalaksmi R. 2009. A Low Cost Nutritious Food "Tempeh"- A Review. World Journal of Dairy and Food Sciences 4 (1): 22-27.

Nakajima N., Nozaki N., Ishihara K. Ishikawa A. and Hideaki T. 2005.
Analysis of Isoflavone Content in Tempeh, a Fermented Soybean, and Preparation of a New IsoflavoneEnriched Tempeh. Journal of Bioscience and Bioengineering. 100 (6): 685-687.

Pahoja, V.M. and Sethar, M.A. 2002. A Review of Enzymatic Properties of Lipases in Plants, Animals, and Microorganisms. Pakistan Journal of Applied Sciences 2(4): 474-484.

Pilli, T.D., Giuliani, R., Derossi, A. and Severini, C. 2008. Effects of Microwave Drying on Lipid Oxidation of Stuffed Pasta. Journal of American Oil Chemistry Society. 85(9): 827-834.

Rahmianna A.A., Ginting E. dan Yusnawan E. 2007. Cemaran Aflatoksin B1 pada Kacang Tanah yang Diperdagangkan di Sentra Produksi Banjarnegara. Penelitian Pertanian Tanaman Pangan. 26 (2): 172144.

Tsav-Wua, J.A., Inyang, C. U. and Akpapunam, M. A. 2004. Microbiological quality of fermented cassava flour 'kpor umilin'. International Journal of Food Sciences and Nutrition 55(4): 317- 324.

Wahono, T. 2007. Panduan Penerapan Pedoman Cara Produksi Pangan Yang Baik Untuk Industri Rumah Tangga (CPPB-IRT). Fakultas Teknologi Pertanian. Universitas Brawijaya. Malang.

Yazdanpanah H., Mohammadi T., Abouhossain G. and Cheraghali $M$. 2005. Effect of Roasting on Degradation of Aflatoxins in Contaminated Pistachio Nuts. Food and Chemical Toxicology. 43 (7): 1135-1139. 